Available online on 15.06.2020 at http://jddtonline.info
Open Access to Pharmaceutical and Medical Research
(C) 2011-18, publisher and licensee JDDT, This is an Open Access article which permits
unrestricted non-commercial use, provided the original work is properly cited

Open 2 Access

Research Article

\title{
Vaccine Preperative Trial for Leptospirosis and their Pathological, Immunological Study by Serum Electrophoresis
}

\author{
Vishnu Kiran Manam ${ }^{* 1}$ and G Sumathi ${ }^{2}$ \\ ${ }^{1}$ PG and Research Department of Microbiology, Jaya College of Arts \& Science, University of Madras, Chennai, Tamilnadu, India - 602024 \\ ${ }^{2}$ Leptospirosis Research Cell, Institute of Microbiology, Madras Medical College, Chennai 600003.Tamilnadu, India
}

\begin{abstract}
Leptospirosis is a fatal infectious disease caused by different serovars of Leptospira spirochetes affecting humans and animals. In the present study, the trials of the whole-cell killed formalin treated monovalent vaccine using Leptospira icterohaemorrhagiae and trivalent vaccine using Leptospira icterohaemorrhagiae, Leptospira louisiana, and Leptospira hebdomadis were studied. The serum electrophoresis studies were done after administration of the vaccine into the experimental albino mice along with the booster dose of the vaccinated serum by densitometric readings. Similarly, the pathological observations were made by dissecting the virulent mice, vaccinated mice, and comparing them with the control mice. The MAT titre was also studied after the booster dose administration of the vaccinated serum. The monovalent and trivalent whole-cell killed formalin treated vaccines shows significant raise in the total proteins, albumin, globulin, $\alpha 1$ globulin, $\alpha 2$ globulin, $\beta$ globulin and $\gamma$ globulins of the serum as well as increase in significant levels in the antibody levels after the administration of the booster dose at an interval of 14 days.
\end{abstract}

Keywords: Leptospira, Whole-cell killed formalin treated vaccine, Immunological study, Pathological study, Serum electrophoresis.

Article Info: Received 26 March 2020; Review Completed 27 May 2020; $\quad$ Accepted 04 June 2020; Available online 15 June 2020

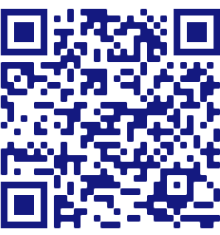

Cite this article as:

Manam VK, Sumathi G, Vaccine Preperative Trial for Leptospirosis and their Pathological, Immunological Study by Serum Electrophoresis, Journal of Drug Delivery and Therapeutics. 2020; 10(3-s):111-127

http://dx.doi.org/10.22270/jddt.v10i3-s.4172

*Address for Correspondence:

Dr Vishnu Kiran Manam, PG and Research Department of Microbiology, Jaya College of Arts \& Science, University of Madras, Chennai,

Tamilnadu, India - 602024

\section{INTRODUCTION:}

Leptospirosis, a zoonotic disease caused by the spirochetal bacteria Leptospira is a common disease of livestock, pet animals with its prevalence worldwide 1 . The geographical distribution of leptospirosis has been overlapping over the decades and produce endemic and epidemic acute febrile diseases ${ }^{2}$. Sporadic outbreaks have been reported from the countries like USA, UK, Australia, New Zealand, parts of Europe, and among Asian countries. The recent incidence of leptospirosis is approximately 1.03 million cases with 58900 associated deaths that have been reported worldwide ${ }^{3}$. In India, Ayyar first isolated Leptospira interrogans serovar Icterohaemorrhagiae from dogs in Chennai, Tamilnadu, India, 4 and from then on the prevalence of leptospirosis have been reported in human and animal species ${ }^{5-8}$. The source of infection occurs through direct or indirect exposure to infected reservoir host animals which carry the leptospires in their renal tubules and shed it in their urine 9 The brown rat (Rattus norvegicus) was considered an important source of infection although many wild and domestic animals can serve as reservoir hosts. Leptospirosis was initially known as Weil's syndrome 10,11 and is mostly an occupational disease affecting humans who come in contact with rodents, pets, and polluted water 12-15. The clinical features of leptospirosis depend on the host and serovar type which may be highly variable and nonspecific. Mostly asymptomatic or subclinical infections occur but when symptoms appear the onset is typically 2 to 30 days after exposure 16. The broad spectrum symptoms of leptospirosis include pneumonitis 17, 18, meningitis 19, nephritis 20-23, hepatitis 24 , pancreatitis 25 and erythema nodosum 26 and death 27, 28. The whole-cell killed vaccines were developed and available in some countries for prevention during endemic and epidemic situations ${ }^{29}$. Apart from the wholecell killed vaccines other vaccines like recombinant protein vaccines, lipopolysaccharide (LPS) vaccines, inactivated and attenuated vaccines, and DNA vaccines have been developed across worldwide 30 . The development of the whole-cell killed vaccine and their subsequent trials have been reviewed and published in the middle of the last century ${ }^{31}$ 34. The targeting and identification of proteins among pathogenic leptospires have become one of the major 
leptospirosis researches as it can provide cross-protection on various serovar groups $35-57$. In the present study, the whole-cell killed formalin treated vaccine preparative trials were conducted in albino mice and their immunological studies were done using serum electrophoresis by densitometric readings and SDS PAGE for determining their molecular weight along with the pathological observation of the dissected albino mice injected with virulent strains and the whole-cell killed formalin treated vaccine prepared compared to that of control mice.

\section{MATERIALS AND METHODS:}

\section{Collection and maintenance of Virulent Leptopspiral serovars}

The virulent serovars of Leptospira icterohaemorrhagiae (Fig 3), Leptospira louisiana (Fig 1), and Leptospira hebdomadis (Fig 2) were collected and maintained at Leptospirosis Research Cell, Institute of Microbiology, Madras Medical College, Chennai, Tamilnadu, India. The Virulent serovars were maintained in Ellinghausen McCullough Johnson \& Harris $(\mathrm{EMJH})$ medium [BD Difco] with a solution of albumin, polysorbate 80 , and additional growth factors for the growth of Leptospira $58-65$ and the final pH $7.5 \pm 0.2$ was maintained (Fig 4). The cultures were incubated for 5 to 7 days at $28-30^{\circ} \mathrm{C}$ and they were checked for the growth and purity of leptospires under dark field microscopy (Nikon SMZ1500) to see that absence of any contamination or clumps or presence of enough quantity of growth. The turbidity of the cultures was checked and compared with 1.0 McFarland's standard for the level of growth as to obtain 2-3 x $10^{8}$ leptospira /ml of media 66 .

Monovalent and Trivalent vaccine preparation trial for Leptospirosis

The monovalent vaccine was prepared using the serovar Leptospira icterohaemorrhagiae and the trivalent vaccine was prepared using serovars Leptospira icterohaemorrhagiae, Leptospira louisiana, and Leptospira hebdomadis at $250 \mathrm{million} / \mathrm{ml}$ concentration (Fig 5). The cultures were killed with formalin (Merck) $(0.5 \mathrm{ml}$ formaldehyde) $\pm 36 \%$ in $100 \mathrm{ml}$ culture. They were kept in room temperature for 30 minutes and the killed leptospires were then heated in a boiling water bath $\left(95^{\circ} \mathrm{C}\right)$ for 30 minutes. They were rotated every 15 minutes and then cooled at room temperature $67-70$.

\section{Experimental inoculation in albino mice}

The albino mice were procured from Tamilnadu Veterinary and Animal Sciences University (TANUVAS), Madavaram, Chennai, Tamilnadu, India. The mice weighed in the range of $18-20 \mathrm{~g}$ in weight. The procured albino mice were brought and maintained at Animal House at Jaya College of Arts \& Science, Chennai, Tamilnadu, India. The mice were maintained separately with proper housing and ventilation. Box type cages were maintained as mice required shaded light with proper bedding materials like sawdust, paddy husk, sugarcane pith, and wood shavings and thoroughly changed at regular intervals. The sanitary condition of the cage is thoroughly checked and cleaned at regular intervals. The feeders and waterers are thoroughly disinfected using moist heat sterilization.

The prepared monovalent and trivalent vaccine was injected into the albino mice at $0.05 \mathrm{ml}$ concentration intramuscularly along with Freund's complete adjuvant (Sigma-Aldrich) ${ }^{71}$. Before inoculation, the albino mice were tested for germ-free status without any infections.

\section{Determination of Serum Globulin profile of inoculated albino mice}

Cardiac puncture of albino mice was made by piercing the needle through skin and musculature of the left intercostal space between sixth and seventh ribs 72 . The heart was palpated before the introduction of the needle and the blood was drawn carefully with $1 \mathrm{ml}$ tuberculin needle and the serum was separated by centrifugation (REMI - R8C). The separated serum from the monovalent and trivalent injected albino mice was compared with the serum of control mice by serum electrophoresis and densitometric readings.

\section{Serum Electrophoresis}

The procured serum from monovalent injected mice, trivalent injected mice, and control mice were subjected to serum electrophoresis. 1\% Agarose was prepared in the trisglycine buffer and $3.5 \mathrm{ml}$ of agarose solution was carefully poured onto a clean glass slide using a pipette that was allowed to form a gel for 15-20 minutes. A few drops of undiluted serum were pipetted on to a clean glass slide and a pinch of bromophenol blue powder was added over it. Then the serum was mixed using a coverslip and stamped on to the gel at one end of the slide. The slide was then placed over the bridges of the apparatus and 75-100 ml of Tris-glycine buffer was poured to each reservoir. The Whatmann -1 filter paper $(3.0 \times 2.5 \mathrm{~cm})$ was wetted in the buffer and place on each side of the gel side and the other end of the paper wick was allowed to touch the buffer. The apparatus was connected to the power supply which was turned on for the electron mobility to run over the gel and the voltage was slowly increased to 100 volts. The gel was allowed to run for 1 to 2 hours till the blue color marker dye reaches the anodic end of the gel. Finally, the power supply was disconnected and the slides were removed and placed in a tray for staining purpose ${ }^{73}$. After staining the slides were removed and dried which were examined for bands on white light transilluminator (BIO-HELIX - BP001CU). The slides were finally subjected to densitometric readings.

\section{Microscopic Agglutination Test (MAT)}

The MAT is a qualitative and quantitative test having high diagnostic specificity and relatively low sensitivity. The microscopic agglutination test (MAT) is the reference test method for the sero-diagnosis of leptospirosis both in humans and in animals (World Health Organization (WHO), 2003; World Organization for Animal Health (OIE), 2008). This test detects antibodies to specific serovars using live leptospiral antigens and can be performed on serum from any species. The serum obtained from the vaccinated experimental mice was given subsequent booster doses at the time interval of 14 days in the range of $1^{\text {st }}, 2^{\text {nd }} \& 3^{\text {rd }}$ and the antibody level was determined by Microscopic Agglutination Test (MAT) ${ }^{74}$.

\section{Pathological Studies:}

The pathological studies were performed by dissecting the mice [virulent mice, vaccinated mice, and control mice] and their physical internal body parts were observed and reported 75 .

\section{RESULTS:}

The whole-cell heat-killed formalin treated monovalent vaccine was prepared using single serovar Leptospira icterohaemorrhagiae and a trivalent whole-cell heat-killed formalin treated vaccine was prepared using serovars Leptospira icterohaemorrhagiae, Leptospira louisiana, and Leptospira hebdomadis. The vaccines monovalent and trivalent were then injected into albino mice (Include 
conditions) intramuscularly and their serum profile was observed by densitometric readings compared with the virulent injected albino mice serum and the control mice serum. The densitometric readings of the serum electrophoresis revealed the presence of total proteins, albumin, globulin, $\alpha 1$ globulin, $\alpha 2$ globulin, $\beta$ globulin, and $\gamma$ globulins in the monovalent, trivalent and virulent injected mice serum as well as in the control mice serum. The total proteins, albumin, globulin, $\alpha 1$ globulin, $\alpha 2$ globulin, $\beta$ globulin and $\gamma$ globulins showed a significant increase in monovalent vaccine injected serum (Fig 7; Graph 2) when compared to control mice serum (Fig 6; Graph 1) and a 2 fold increase of total proteins, albumin, globulin, $\alpha 1$ globulin, $\alpha 2$ globulin, $\beta$ globulin, and $\gamma$ globulins were observed in trivalent vaccine injected serum (Fig 8; Graph 3 ). The booster dose of the monovalent and trivalent vaccines along with Freund's adjuvant was given at an interval of every 14 days interval and the antibody level was determined. The microscopic agglutination titre (MAT) (Fig $9 \& 10$ ) revealed the significant increase in the antibody levels after the administration of the booster dose in the ratio 1:05 (1 $1^{\text {st }}$ booster dose), 1:20 ( $2^{\text {nd }}$ booster dose) and 1:40 (3rd booster dose). The pathological studies revealed the enlargement of internal organs of the virulent strains injected albino mice such as spleen, liver, heart intestine, etc. which were absent when compared with the control and vaccinated albino mice.

\section{DISCUSSION :}

The whole-cell killed formalin treated vaccines from the present study showed a significant increase in the serum profile when compared to control mice serum especially 2 fold increase was observed with trivalent injected vaccine serum. Similarly, the antibody levels by microscopic agglutination test showed an increase in the antibody levels on every booster dose at an interval of 14 days. It is known that heat or chemical treatment of leptospires changes their effectiveness as vaccines. The phenol, Formalin, and thimerosal remove the outer envelope and damage the protoplasmic cylinder was reported during 1965 in an ultrastructure study ${ }^{76}$. It is known that Formalin treated antigens have lower sensitivity and greater cross-reactivity in the MAT 77 . The effectiveness of the killed vaccine is serovar specific which was documented in various studies 78 , 79. The variability of serovars in the locality of endemic leptospiral strains makes it difficult to construct a vaccine that can be used worldwide ${ }^{80}$. Studies revealed that heatkilled inactivated vaccine induces a strong antigen-specific proliferative response by peripheral blood mononuclear cells (PBMC) which was reported in vaccinated cattle after 2 months of the initial booster dose 81 . The whole-cell killed vaccine in the study illustrated that the antibody levels were low [1:05] during first booster dose and the significant increase in the antibody levels were observed in the $2^{\text {nd }}$ booster dose (1:20) and $3^{\text {rd }}$ booster dose (1:40) so this confirms an elevated immune response after successive booster doses (Graph 4) 82. The pathological studies confirmed that the vaccinated mice (Fig 13) showed no significant change when compared to that of control mice (Fig 11) in the internal body organs whereas the combination of virulent serovars injected into the albino mice (Fig 12) showed severe enlargement of the organs such as spleen, liver, pancreas, etc. The results from the serum electrophoresis and densitometric readings, antibody elevation levels of the vaccinated animals confirmed from MAT titers as well as the pathological studies confirm and form the basis for the development of potent leptospiral vaccines for both epidemic and endemic cases of leptospirosis with new molecular biological tools and advance research systems.

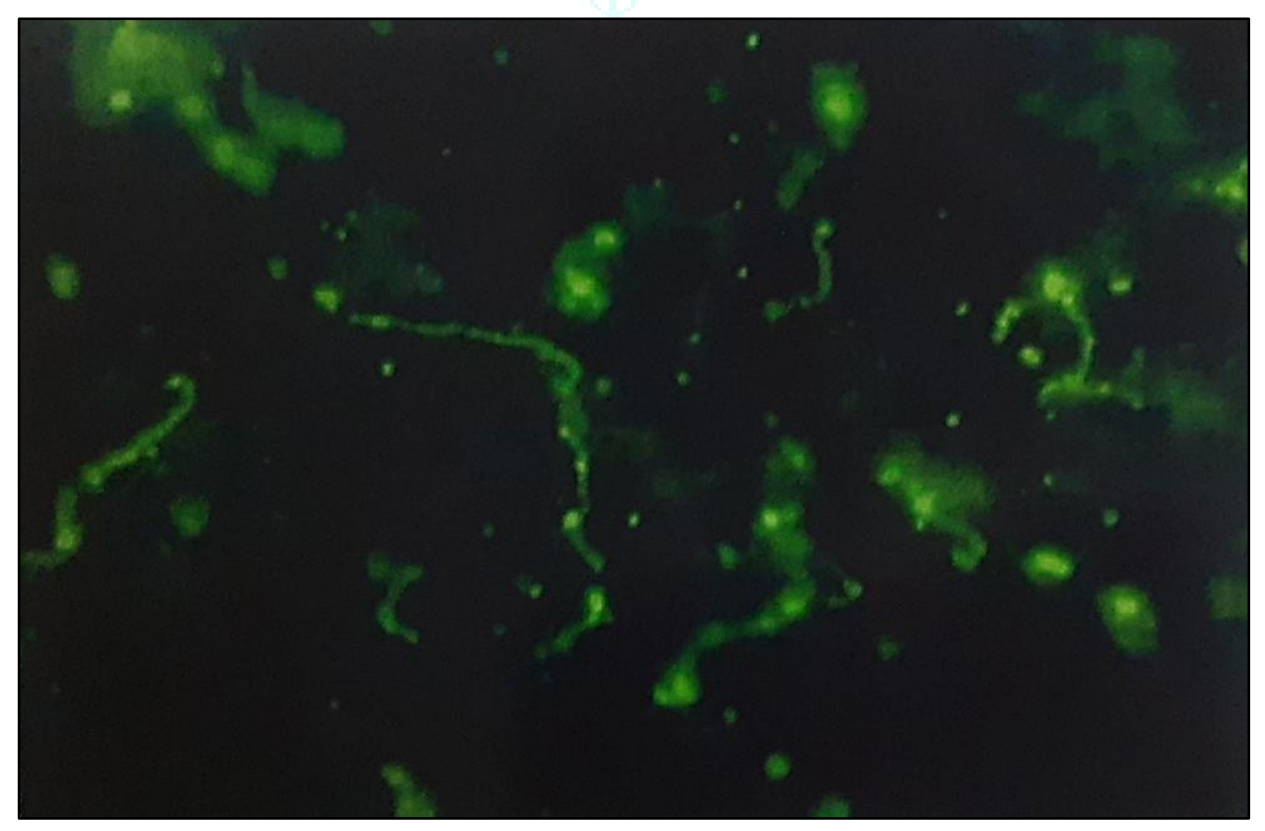

Figure 1: Leptospira louisiana under Fluorescence Microscopy 


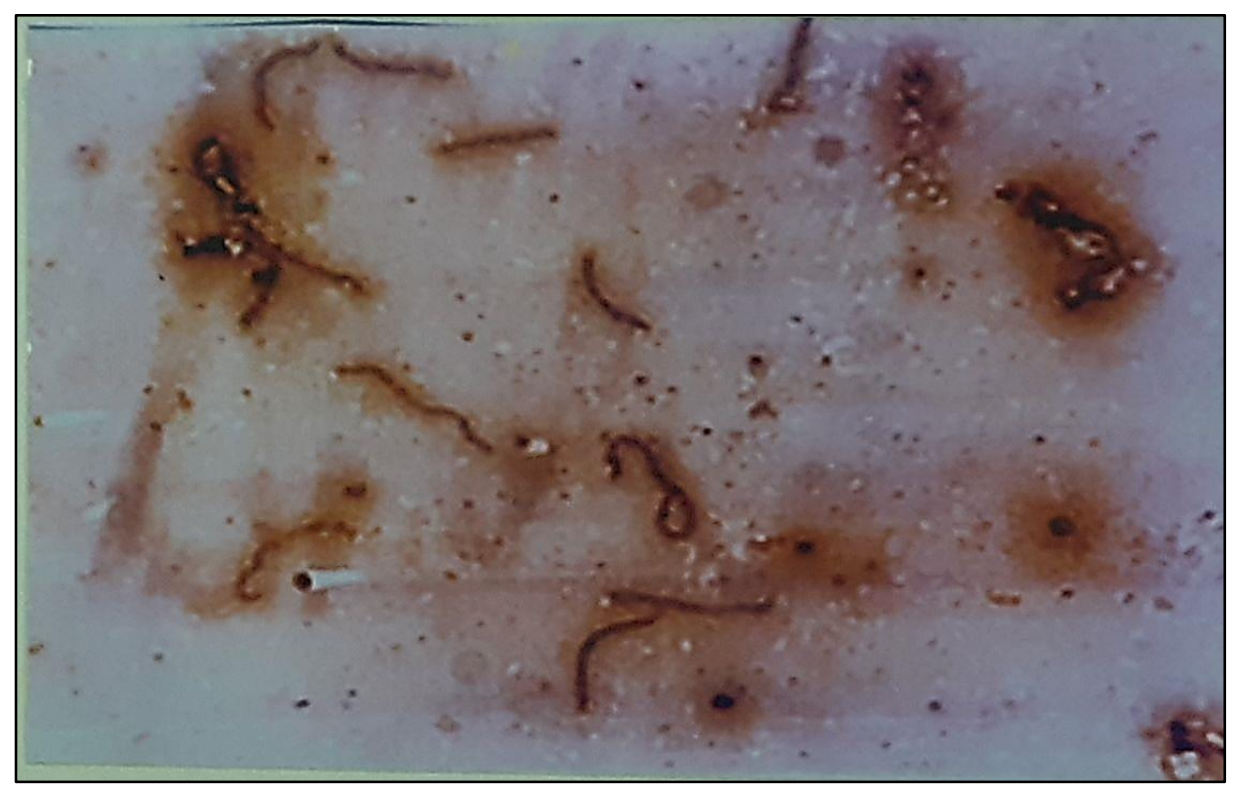

Figure 2: Leptospira hebdomadis under High Power Microscopy

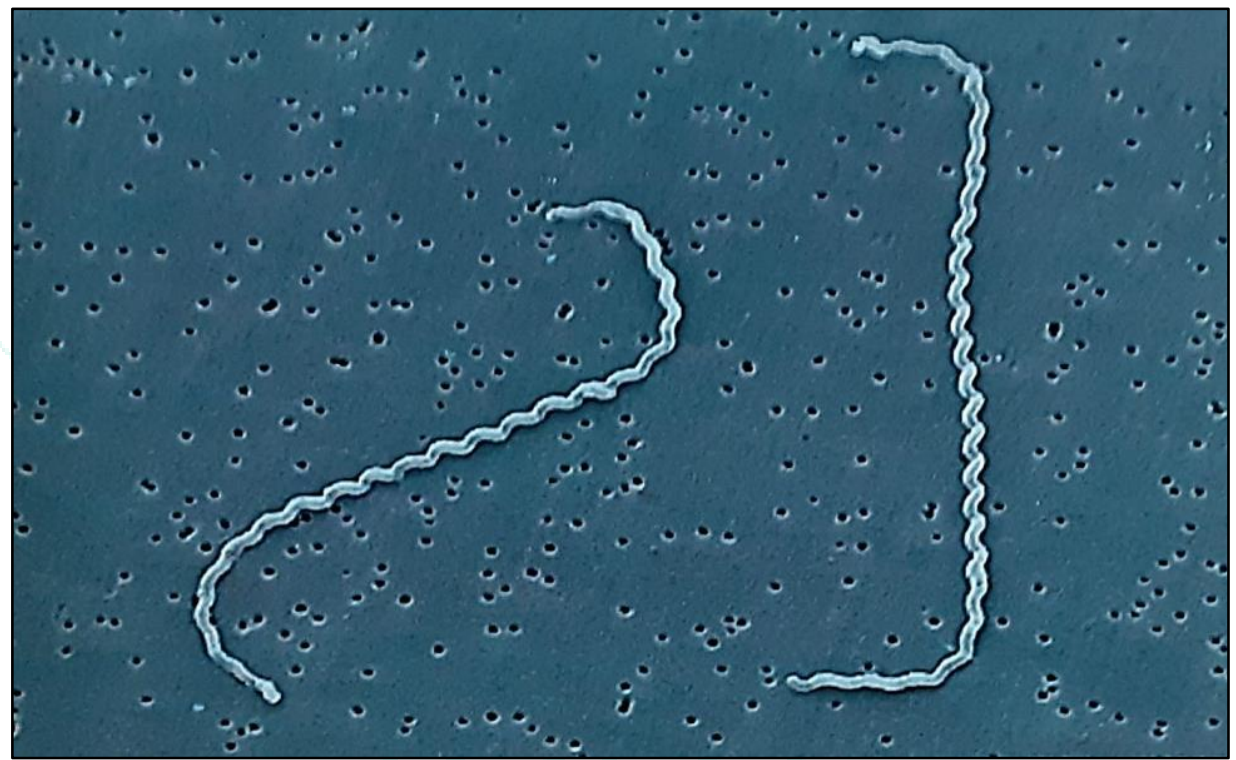

Figure 3: Leptospira icterohaemorrhagiae under Scanning Electron Microscopy

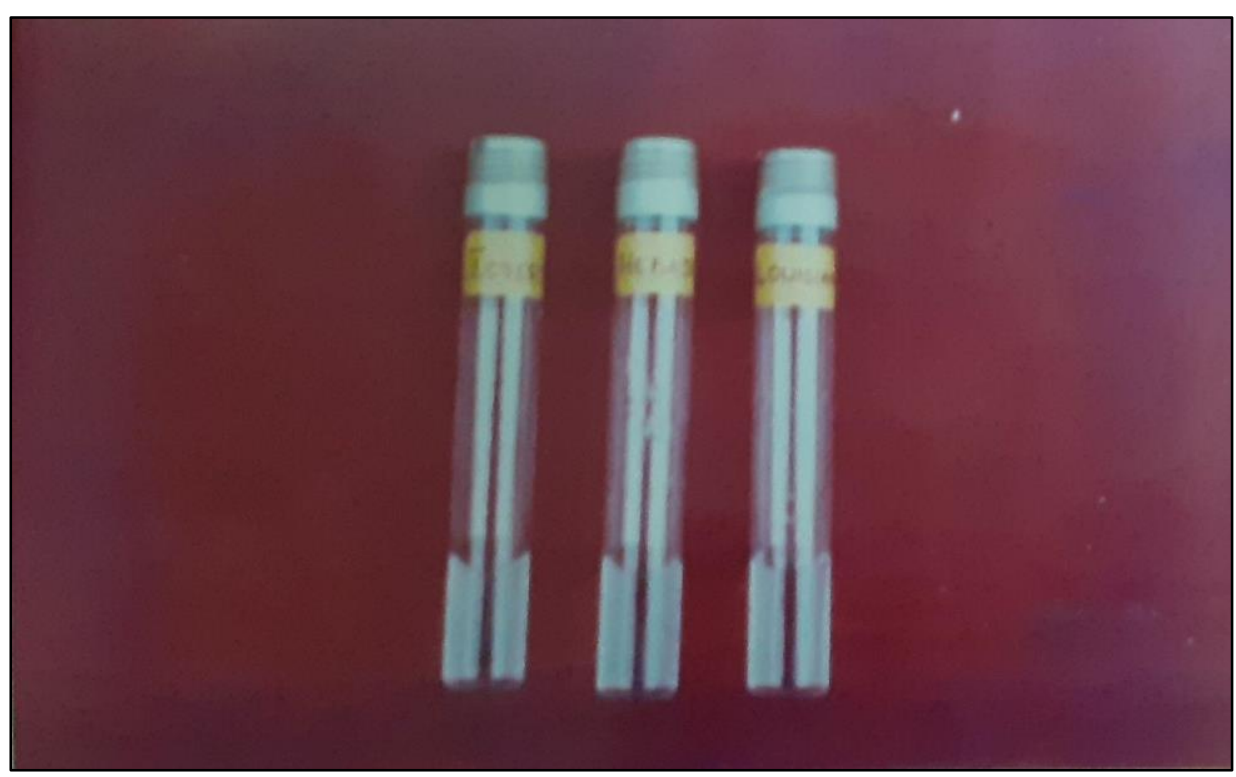

Figure 4: Virulent serovars of Leptospira icterohaemorrhagiae, Leptospira louisiana, and Leptospira hebdomadis in EMJH enriched media. 


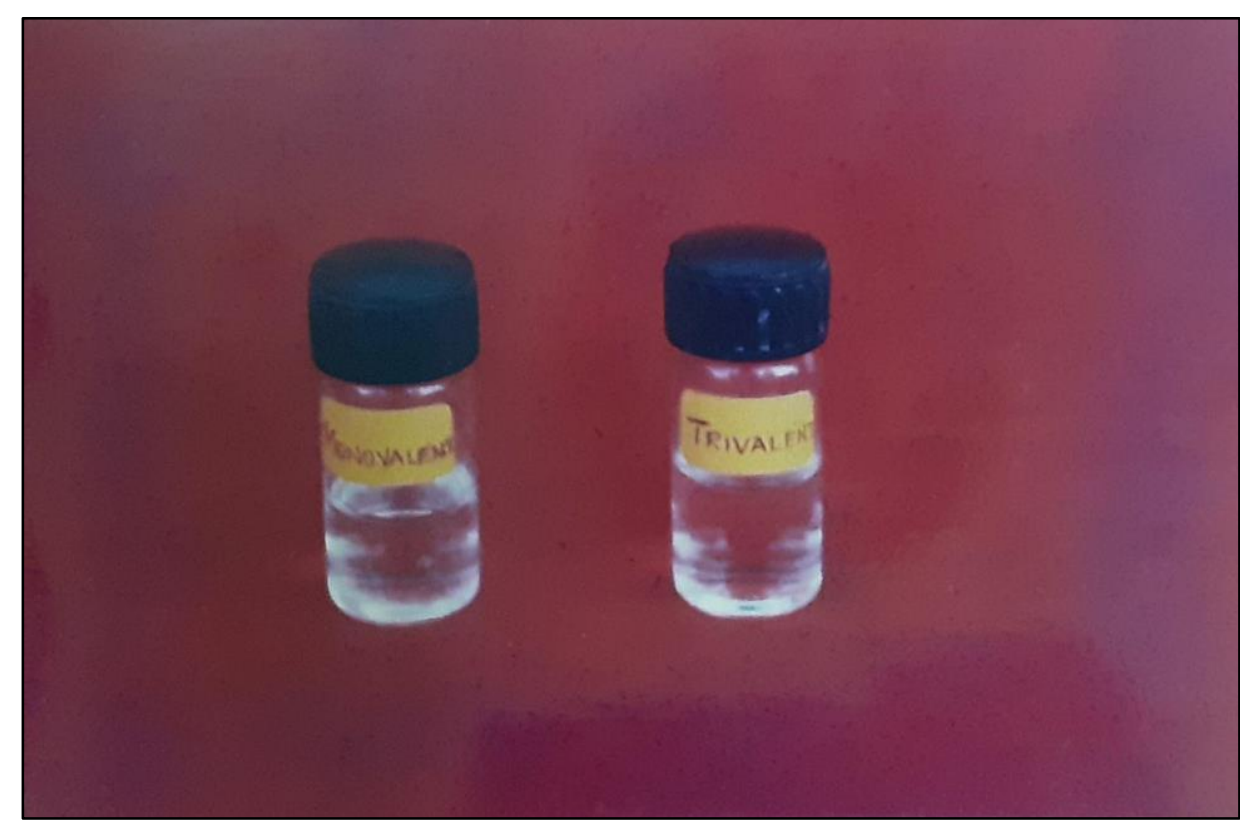

Figure 5: Whole-cell killed formaldehyde-treated monovalent and trivalent vaccine

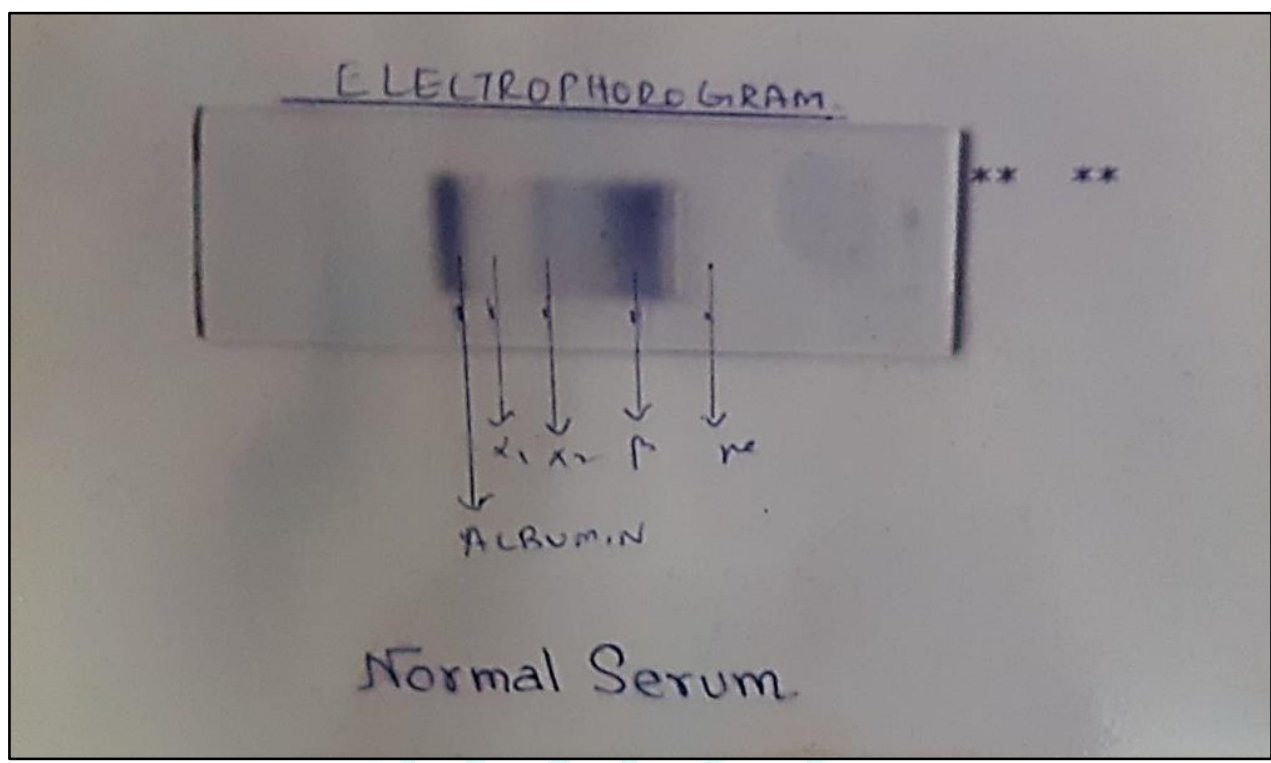

Figure 6: Electropherogram of control albino mice serum

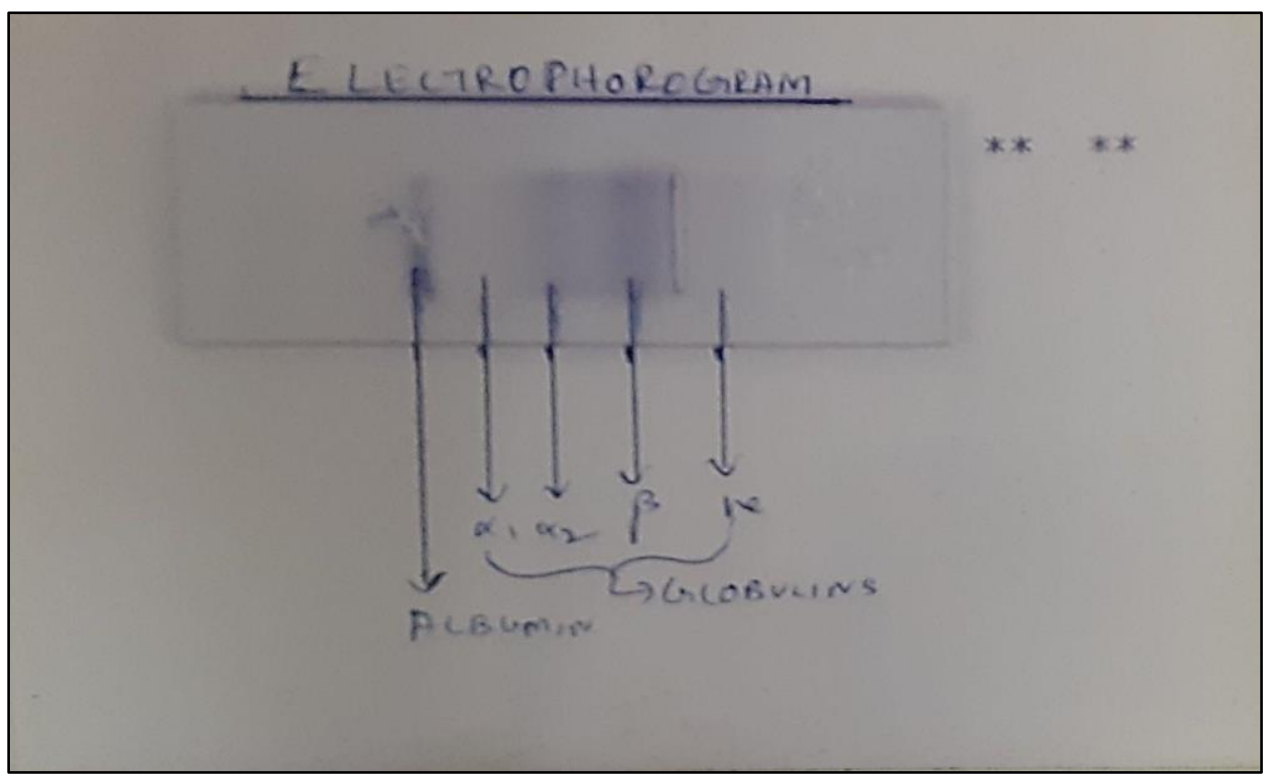

Figure 7: Electropherogram of monovalent albino mice serum 


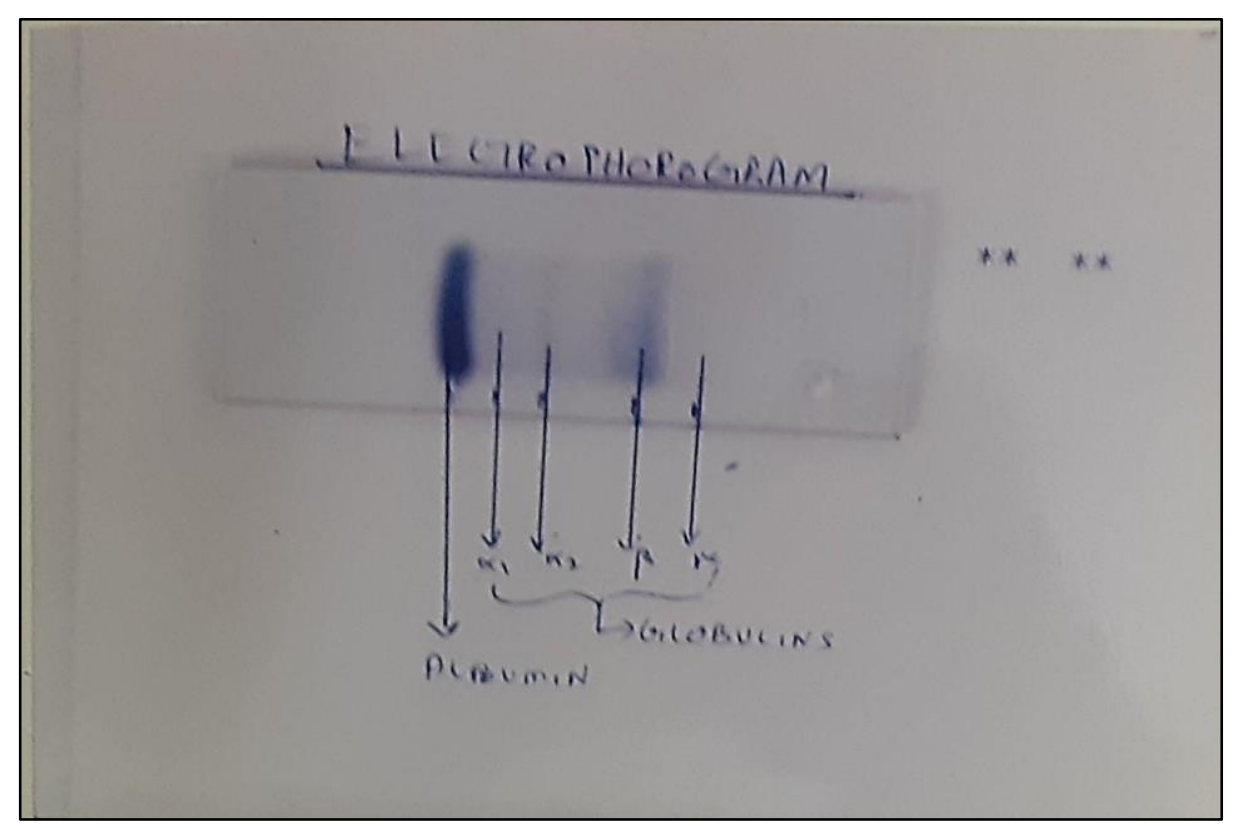

Figure 8: Electropherogram of trivalent albino mice serum

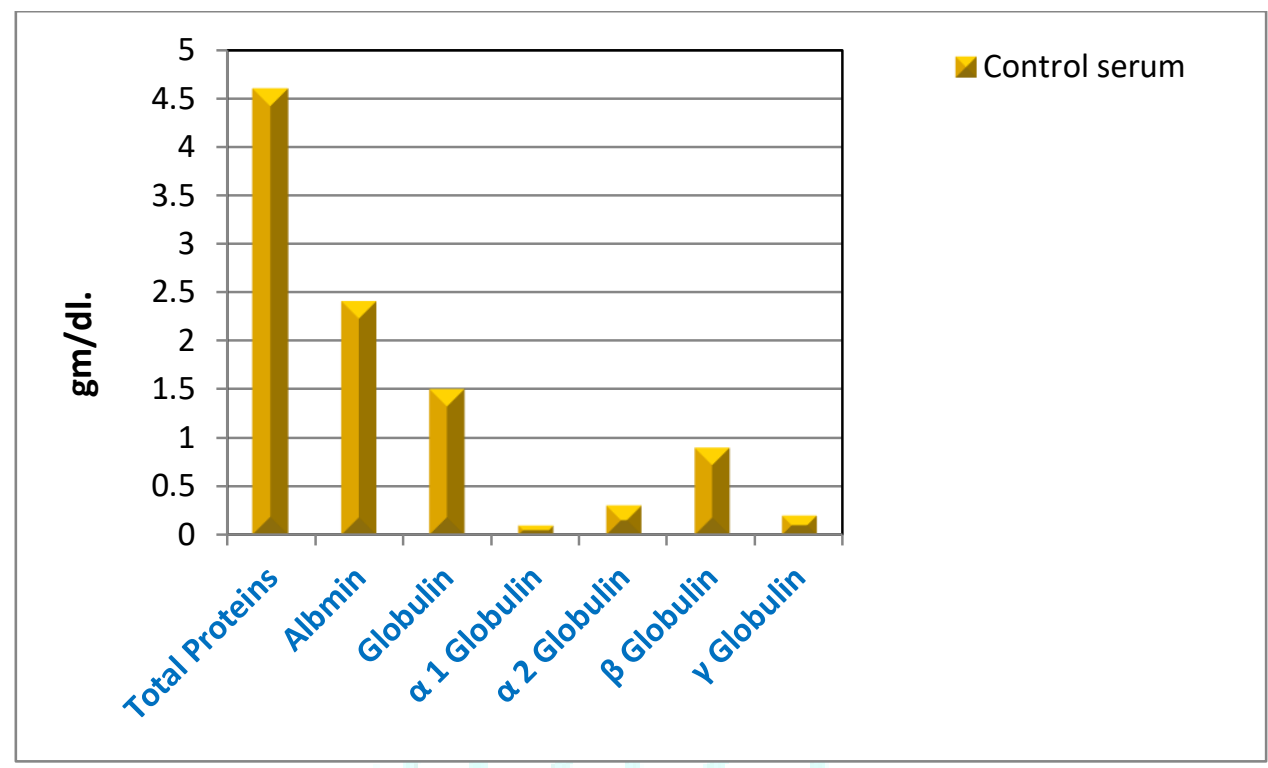

Graph 1: Serum profile of the control albino mice

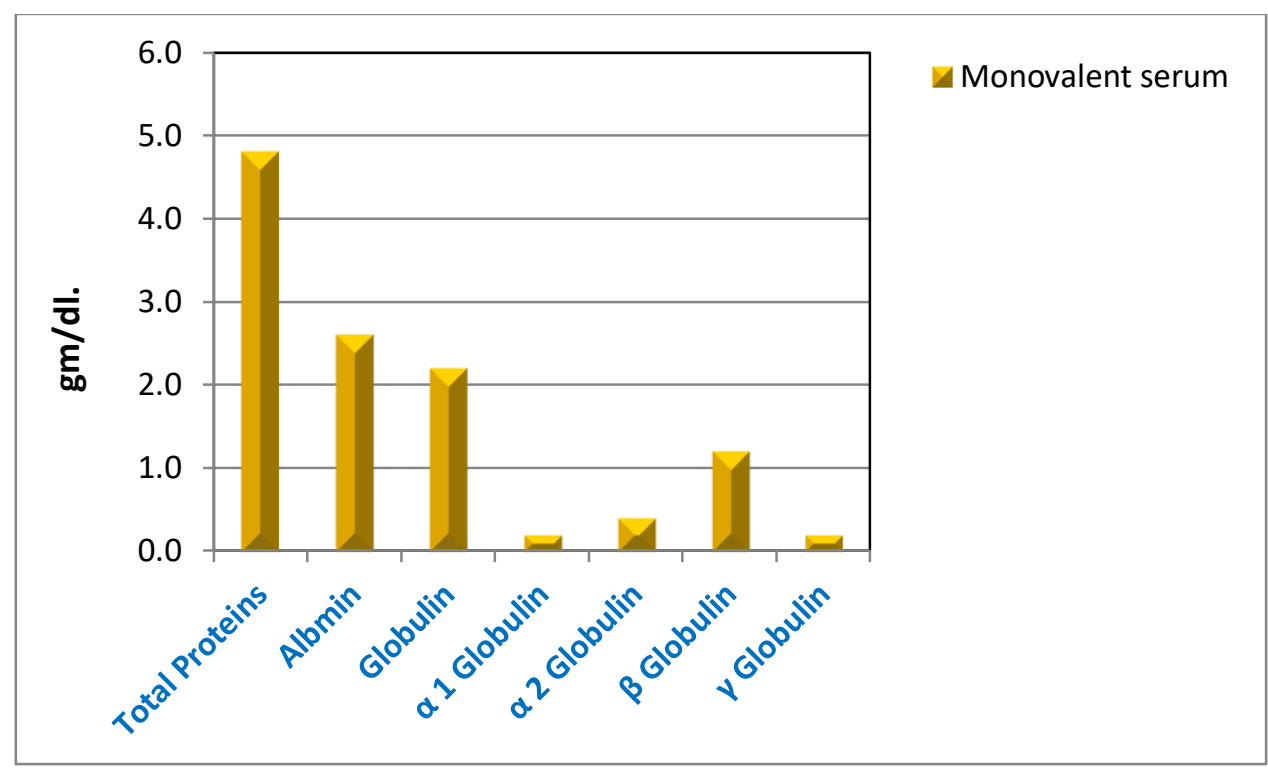

Graph 2: Serum profile of the monovalent vaccinated albino mice 


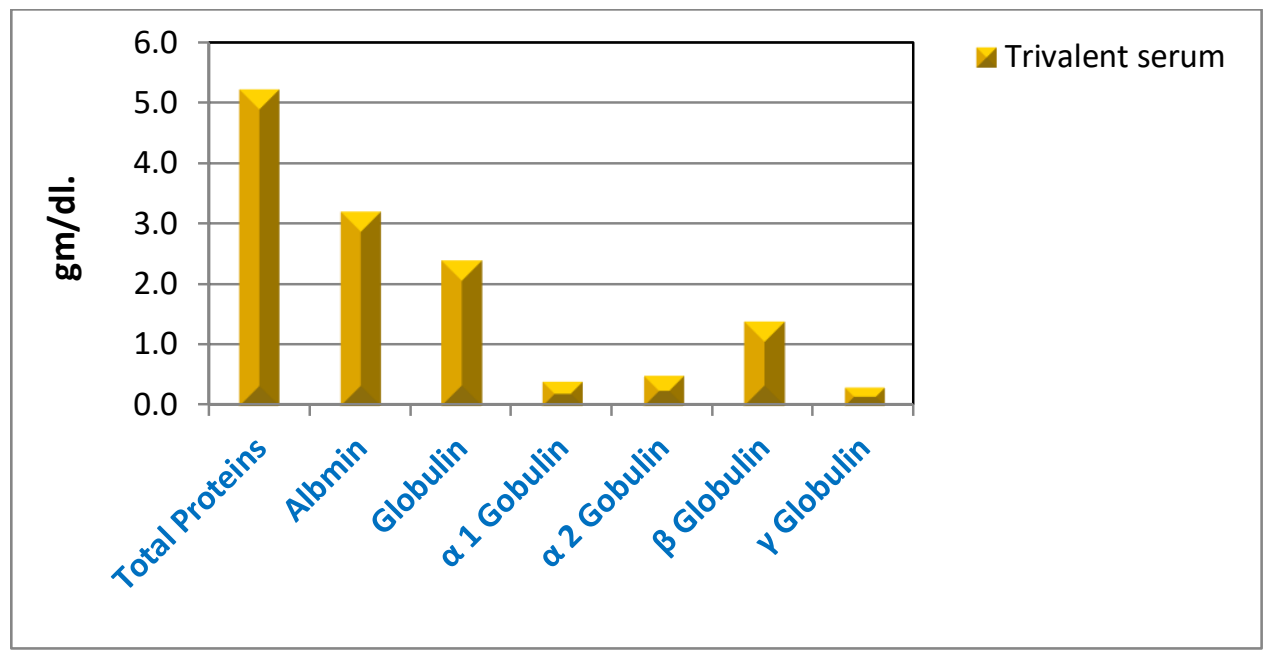

Graph 3: Serum profile of the trivalent vaccinated albino mice

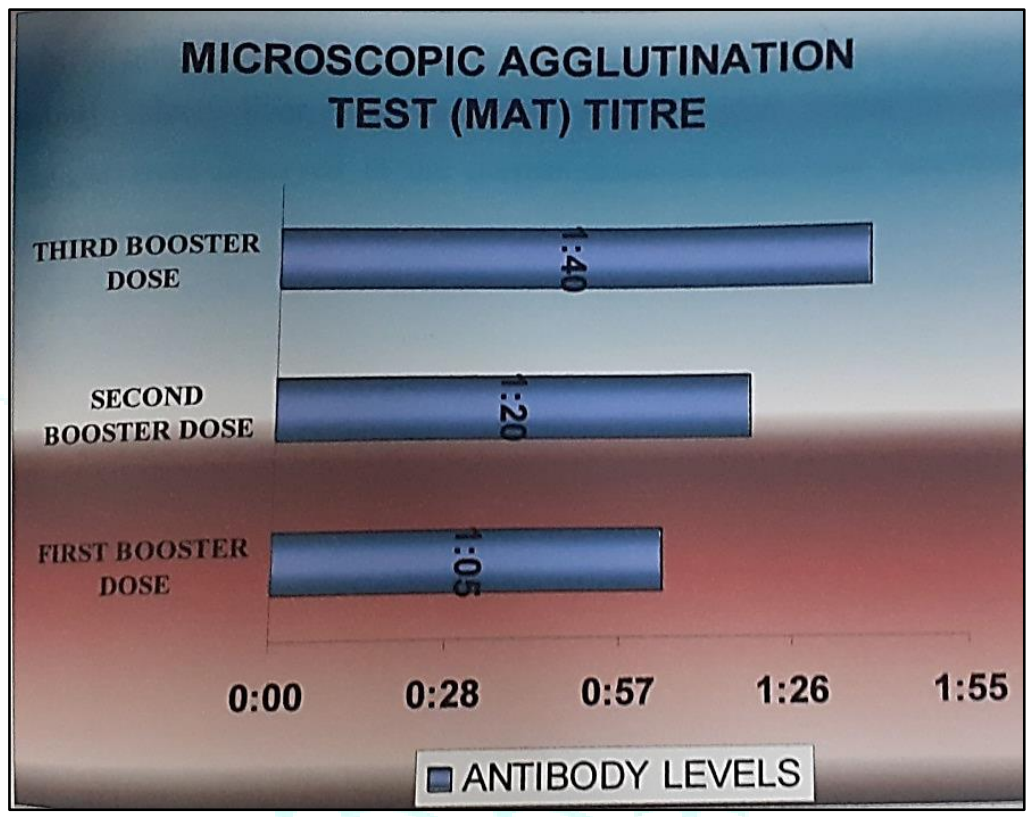

Graph 4: Antibody levels of 3 booster doses with Freund's adjuvant [14 days interval]

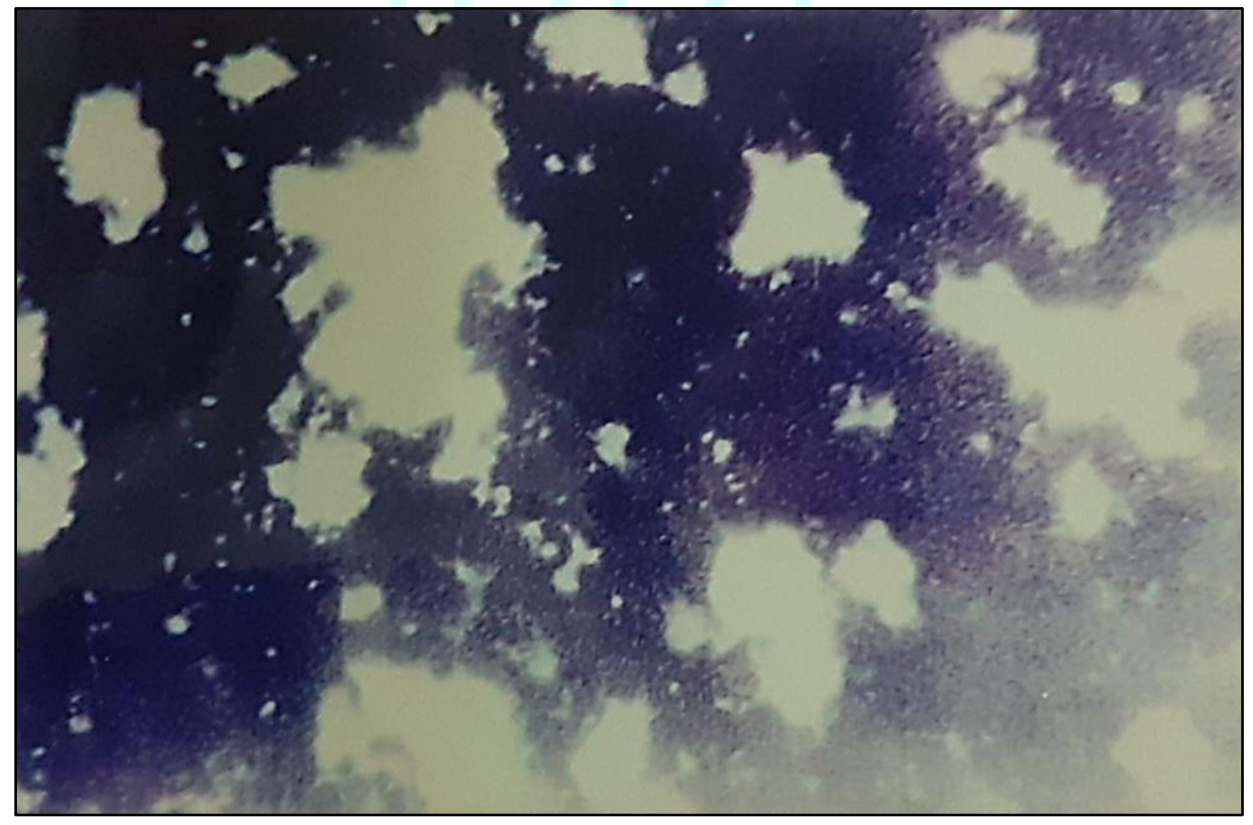

Figure 9: Positive reaction of microscopic agglutination test [MAT] 


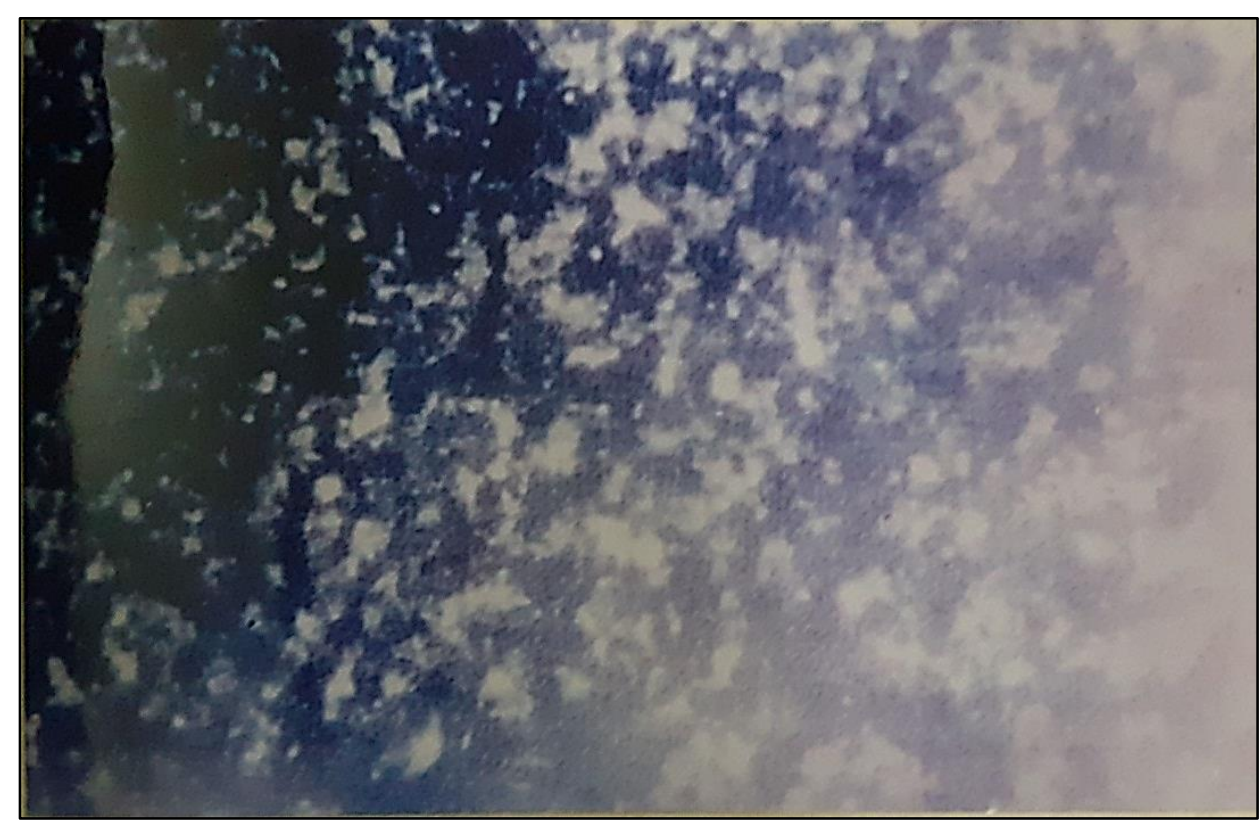

Figure 10: Negative reaction of microscopic agglutination test [MAT]

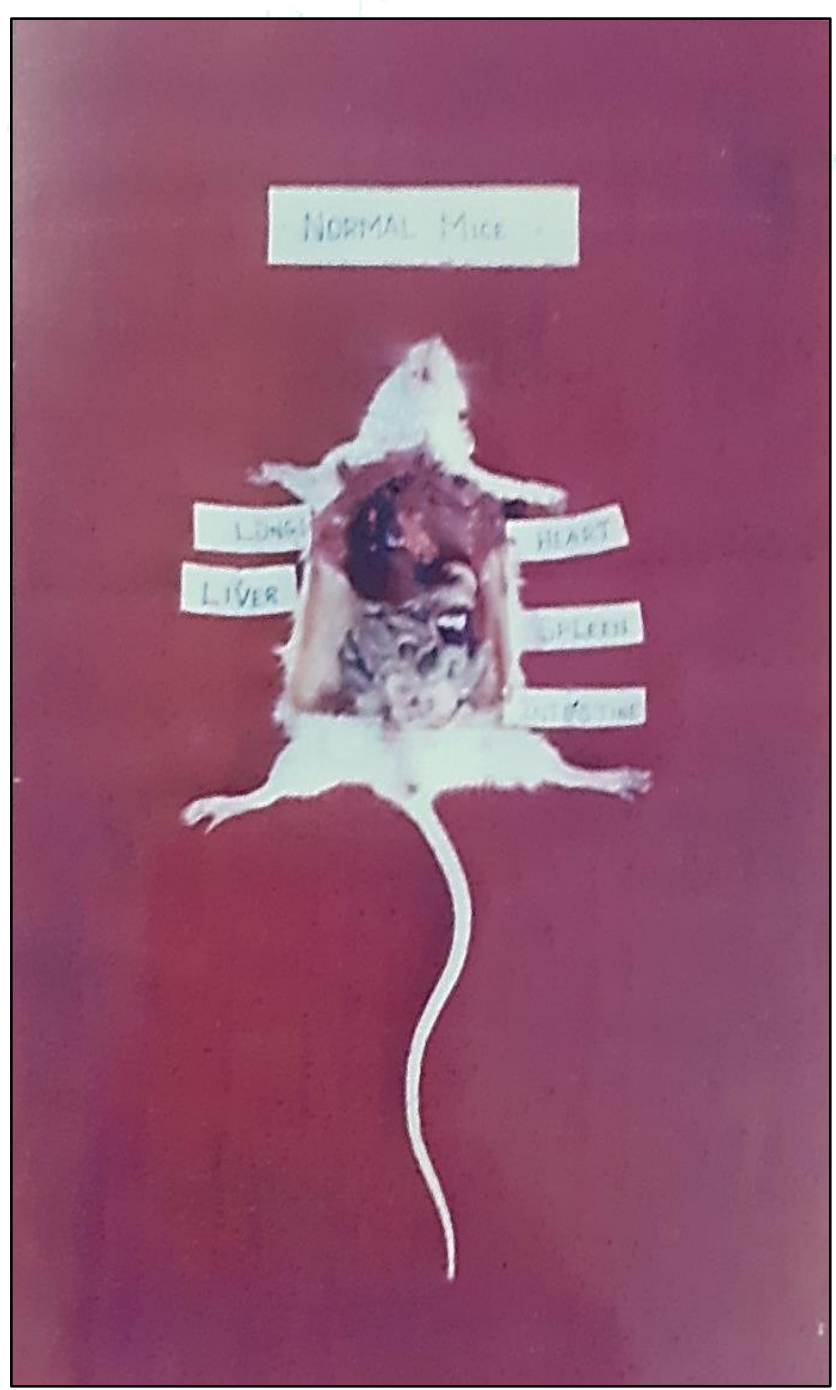

Figure 11: Pathological observation of the dissected control mice 


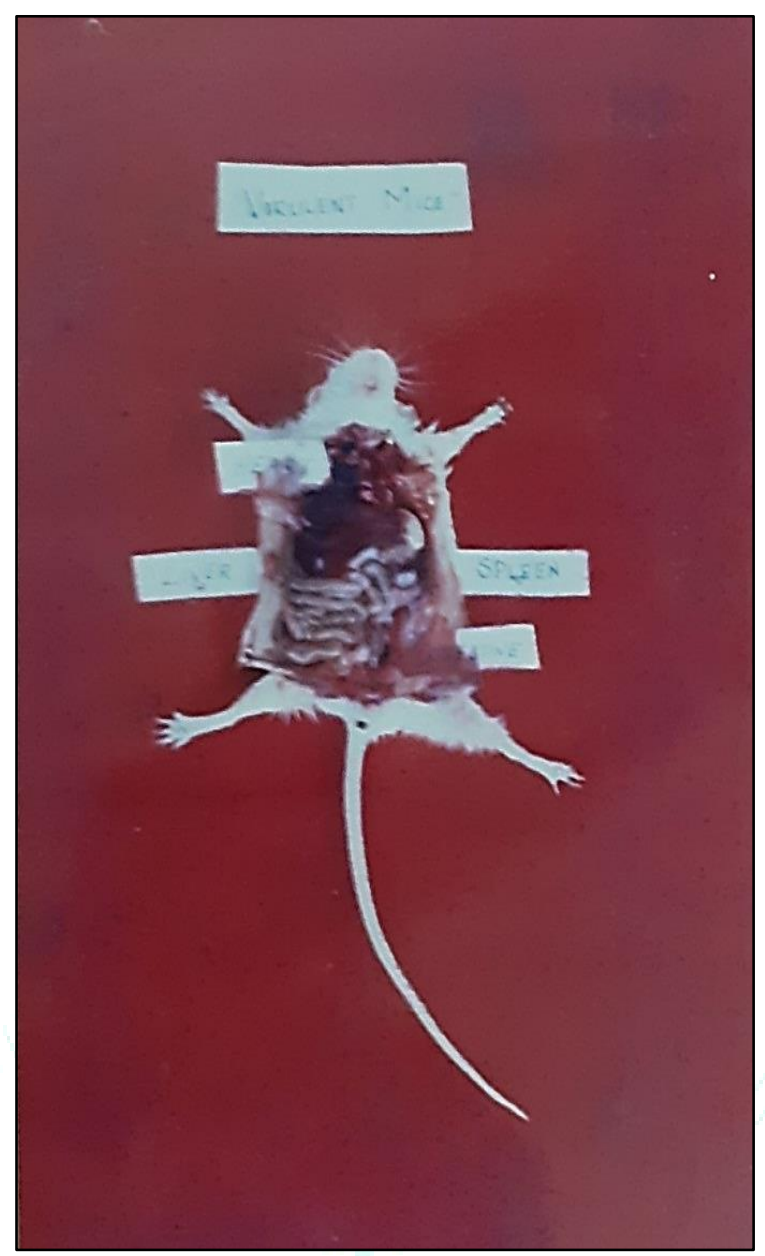

Figure 12: Pathological observation of the dissected virulent mice

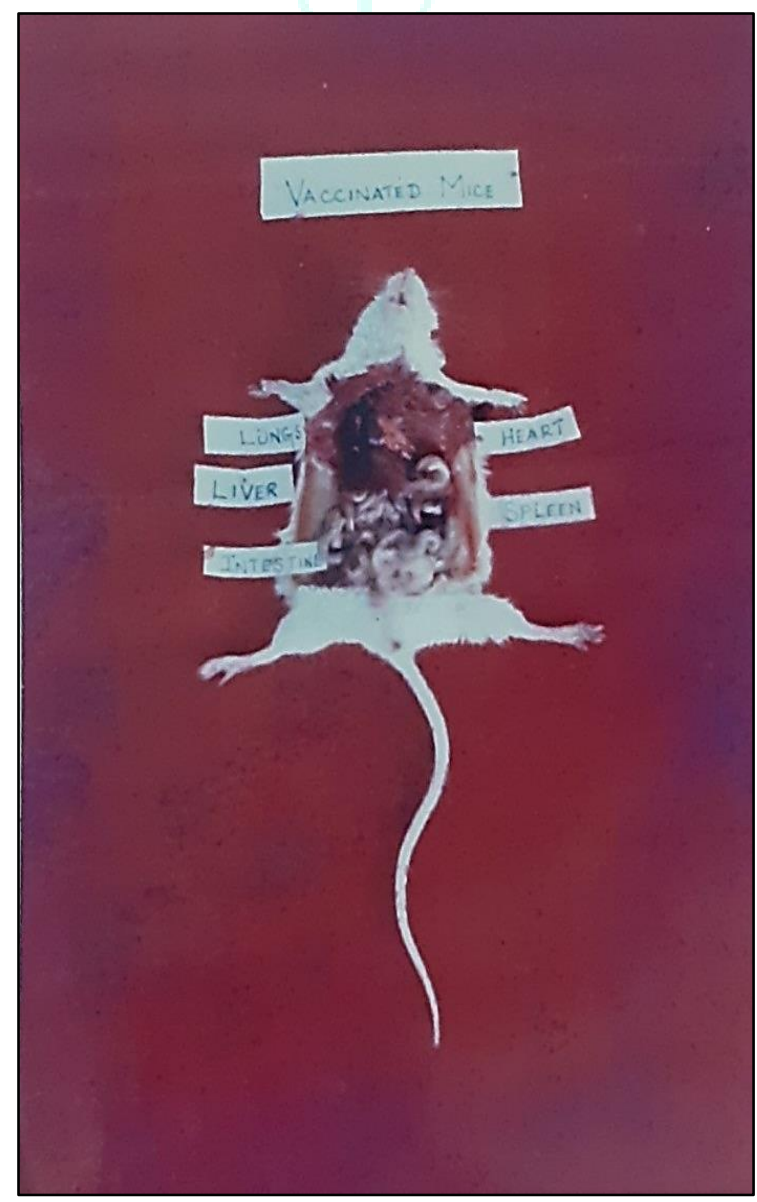

Figure 13: Pathological observation of the dissected Vaccinated mice 


\section{ACKNOWLEDGEMENT}

The authors thank the following institutions

1. Leptospirosis Research Cell, Institute of Microbiology, Madras Medical College, Chennai, Tamilnadu, India for providing the Leptospiral cultures and the MAT set up.

2. Hi-Tech Laboratories, Chennai, Tamilnadu, India for their serum electrophoresis work.

3. Tamilnadu Veterinary and Animal Sciences University (TANUVAS), Madavaram, Chennai, Tamilnadu, India for providing the albino mice.

4. Jaya College of arts \& science, Chennai, Tamilnadu, India for the animal house facility and other equipment.

\section{AUTHORS CONTRIBUTION STATEMENT}

Dr Vishnu Kiran Manam designed and performed the work whereas Dr G. Sumathi suggested the relevant changes during the course of the work and the proofreading of the manuscript.

\section{CONFLICT OF INTEREST}

Conflict of interest declared none.

\section{REFERENCES}

[01] Alison BL, Michael MD, "Leptospirosis: A clinical review of evidence based diagnosis, treatment and prevention" World J Clin Infect Dis, 2016; 6(4):61-66.

[02] Clinton KM, Michael WE, Duaner H, "Susceptibility of Leptospira serovars to antimalarial agents" Am. J. Trop. Med. Hyg, 2004; 71(5):685-686.

[03] Costa F, Hagan JE, Calcagno J, Kane M, Torgerson P, MartinezSilveira MS, Stein C, Abela-Ridder B, Ko AI, "Global Morbidity and Mortality of Leptospirosis: A Systematic Review" PLoS Negl Trop Dis, 2015; 9:e0003898.

[04] Ayyar VK, "A note on the outbreak of leptopspiral jaundice among madras bounds" Indian J Vet Sci, 1932; 2:169.

[05] Adinarayanan N, Jain NC, Chandiramani HK, Haleja SK, "Studies on leptospirosis among bovines in India: A preliminary report on the occurrence in cattle based on serological evidence" Indian Vet J, 1960; 37:251.

[06] Sane CR, Desphande BR, "Record of detection of Leptospira Pomona infection as a cause of abortion in calves -letters to the editor. IVJ" Indian Vet J, 1965; 42:75.

[07] Rajasekhar M, Nanjiah RD, "Animal leptospirosis in Mysore state: A serological study” India Vet J, 1971; 48:1087.

[08] Srivastava SK, Singh SP, Srivastava NC, "Seroprevalance of leptospirosis in animals and man in India" Indian J Comp Microbiol Immunol Infect Dis, 1983; 4:243.

[09] David AH, Paul NL, "Leptospirosis in Humans" Curr Top Microbiol Immunol, 2015; 387:65-97.

[10] McBride AJ, Athanazio DA, Reis MG, Ko AI, "Leptospirosis" Curr Opin Infect Dis, 2005; 18:376-386.

[11] Looke DF, "Weil's syndrome in a zoologist" Med J Aust, 1986; 144:600-601.

[12] Trueba G, Zapata S, Madrid K, Cullen P, Haake D, "Cell aggregation: a mechanism of pathogenic Leptospira to survive in fresh water" Int Microbiol, 2004; 7:35-40.

[13] Levett PN, "Leptospirosis" Clin Microbiol Rev, 2001; 14:296326.

[14] Kuriakose M, Eapen CK, Paul R, "Leptospirosis in Kolenchery, Kerala, India: epidemiology, prevalent local serogroups and serovars and a new serovar" Eur J Epidemiol, 1997; 13:691-697.
[15] Waitkins SA, "Leptospirosis as an occupational disease" Br J Ind Med, 1986; 43:721-725.

[16] WHO. Human leptospirosis: guidance for diagnosis, surveillance, and control. Switzerland: WHO, Geneva, 2003.

[17] Dolhnikoff M, Mauad T, Bethlem EP, Carvalho CR, "Leptopspiral pneumonias" Curr Opin Pulm Med, 2007; 13:230-235.

[18] Bethlem EP, Carvalho CR, "Pulmonary leptospirosis" Curr Opin Pulm Med, 2000; 6:436-441.

[19] Souza AL, Sztajnbok J, Marques SR, Seguro AC, "Leptospirosis induced meningitis and acute renal failure in a 19-month-old male child" J Med Microbiol, 2006; 55:795-797.

[20] Daher E, Zanetta DM, Cavalcante MB, Abdulkader RC, "Risk factors for death and changing patterns in leptospirosis acute renal failure" Am J Trop Med Hyg, 1999; 61:630-634.

[21] Morsi HM, Shibley GP, Strother HL, "Renal leptospirosis: challenge exposure to vaccinated and non-vaccinated cattle to Leptospira icterohaemorrhagiae and Leptospira canicola" Am J Vet Res, 1973; 34:175-179.

[22] Schreiber P, Martin V, Najbar W, Sanquer A, Gueguen S, Lebreux $B$, "Prevention of renal infection and urinary shedding in dogs by a Leptospira vaccination" Vet Microbiol, 2005; 108:113-118.

[23] Broughton ES, Scarnell J, "Prevention of renal carriage of leptospirosis in dogs by vaccination" Vet Rec, 1985; 117:307311.

[24] Adamus C, Buggin-Daubie M, Izembart A, Sonrier-Pierre C Guigand L, Masson MT, Andre-Fontaine G, Wyers M, "Chronic hepatitis associated with leptospiral infection in vaccinated beagles" J Comp Pathol, 1997; 117:311-328.

[25] Spichler A, Spichler E, Moock M, Vinetz JM, Leake JA, “Acute pancreatitis in fatal anicteric leptospirosis" Am J Trop Med Hyg, 2007; 76:886-887.

[26] Derham RL, Owens GG, Wooldridge MA, "Leptospirosis as a cause of erythema nodosum" Br Med J, 1976; 2:403-404.

[27] Katz AR, Ansdell VE, Effler PV, Middleton CR, Sasaki DM, "Assessment of the clinical presentation and treatment of 353 cases of laboratory-confirmed leptospirosis in Hawaii, 19741998" Clin Infect Dis, 2001; 33:1834-1841.

[28] Christova I, Tasseva E, Manev H, "Human leptospirosis in Bulgaria, 1989-2001: epidemiological, clinical, and serological features" Scand J Infect Dis, 2003; 35:869-872.

[29] Koizumi N, Watanabe H, “Leptospirosis Vaccines: Past, Present and Future" J Postgrad Med, 2005; 51(3):210-214.

[30] Zhijun W, Li J, Alicja W, “Leptospirosis vaccines” Microbial Cell Factories, 2007; 6:39.

[31] Babudieri B, "Vaccine against Leptospirosis" Fifth international meeting of biological standardization. Science press of Israel. Jerusalem, the Weizmann; 1959 p 313-350.

[32] Chen TZ, "Development and present state of leptospiral vaccine and technology of vaccine production in china" Jap J Bacteriol, $1985 ; 40: 755-762$.

[33] Sanchez RM, Sierra AP, Suarez MB, Alvarez AM, Hernandez JM, Gonzalez MD, "Evaluation of the effectiveness of new vaccine against human leptospirosis in groups at risk" Rev Panam Salud Publica, 2000; 8:385-392.

[34] Martinez R, Perez A, Quinones M, Cruz R, Alvarez A, Armesto M, "Efficacy and safety of a vaccine against human leptospirosis in Cuba" Rev Panam Salud Publica, 2004; 45:249-255.

[35] Haake DA, Walker EM, Blanco DR, Bolin CA, Miller MN, Lovett MA, "Changes in the surface of Leptospira interrogans serovar grippotyphosa during Invitro cultivation" Infect Immun, 1991; 59:1131-1140.

[36] Haake DA, Champion CI, Martinich C, Shang ES, Blanco DR Miller JN, "Molecular cloning and sequence analysis of the gene encoding $0 \mathrm{mpL} 1$, a trans memmbrane outer protein of pathogenic Leptospira spp" J Bacteriol, 1993; 175:4225-4234. 
[37] Shang ES, Summers TA, Haake DA, "Molecular cloning and sequence analysis of the gene encoding LipL41, a surface exposed Lipoprotein of pathogenic Leptospira spp" Infect Immun, 1996; 64:2322-2330.

[38] Haake DA, Martinich C, Summers TA, Shang ES, Pruetz JD, McCoy AM, "Characterization of leptospiral outer membrane lipoprotein Lip L36: Down regulation associated with late-log phase growth and mammalian infection" Infect Immun, 1998; $66: 1579-1587$.

[39] Park SH, Ahn BY, Kim MJ, "Expression and immunologic characterization of recombinant heat shock protein 58 of Leptospira species: a major target antigen of humoral immune response" DNA Cell Biol, 1999; 18:903-910.

[40] Haake DA, Mazel MK, McCoy AM, Milward F, Chao G, Matsunaga J, "Leptospiral outer membrane proteins OmpL 1and Lip L41 exhibit synergistic immunoprotection" Infect Immun, 1999; 67:6572-6582.

[41] Haake DA, Chao G, Zuerner RL, Barnett JK, Barnett D, Mazel M, "The leptospiral major outer membrane protein Lip L32 is a lipoprotein expressed during mammalian infection" Infect Immun, 2000; 68:2276-2285.

[42] Guerrerio H, Croda J, Flannery B, Mazel M, Matsunaga J, Galvao RM, "Leptospiral proteins recognized during the humoral immune response to Leptospirosis in humans" Infect Immun, 2001; 69:4958- 4968.

[43] Branger C, Sonrrier C, Chatrenet B, Klonjkowski B, RuvoenClouet N, Aubert A, "Identification of the haemolyis associated protein 1as a cross protective immunogen of Leptospira interrogans by adenovirus mediated vaccination" Infect Immun, 2001; 69:6831- 6838 .

[44] Nally JE, Artiushin S, Timoney JF, "Molecular characterization of thermo induced immunogenic proteins Q1p42 and Hsp 15 of Leptospira interrogans". Infect Immun, 2001; 69: 7616- 7624.

[45] Matsunaga J, Young TA, Barnett JK, Barnett D, Bolin CA, Haake DA, "Novel $45 \mathrm{Kda}$ leptospiral protein that is processed to 31 Kda growth phase regulated peripheral membrane protein" Infect Immun, 2002; 70:323-324.

[46] Cullen PA, Cordwell SJ, Bulach DM, Haake DA, Adler B, “Global analysis of outer membrane proteins from Leptospira interrogans serovar Lai" Infect Immun, 2002; 70:2311 - 2318.

[47] Haake DA, Matsunaga J, "Characterization of the leptospiral outer membrane and description of the three novel leptospiral membrane proteins" Infect Immun, 2002; 70:4936- 4945.

[48] Palaniappan RU, Chang YF, Jusuf SS, Artiushin S, Timoney JF, McDonough SP, "Cloning and molecular characterization of immunogenic Lig A protein of Leptospira interrogans" Infect Immun, 2002; 70:5924-5930.

[49] Koizumi N, Watanabe H, "Identification of novel antigen of pathogenic Leptospira spp. That reacted with the convalescent Mice sera" J Med Microbiol, 2003; 52:585-589.

[50] Koizumi N, Watanabe H, "Molecular cloning and characterization of a novel leptospiral lipoprotein with OmpA domain" FEMS Microbiol Lett, 2003; 226:215-219.

[51] Cullen PA, Haake DA, Bulach DM, Zuerner RL, Adler B, “Lip L21 is a novel surface exposed lipoprotein of pathogenic Leptospira species" Infect Immun, 2003; 71:2414-2421.

[52] Matsunaga J, Barocchi MA, Croda J, Young TA, Sanchez Y, Siqueria I, "Pathogenic Leptospira species express surface exposed proteins belonging to the bacterial immunoglobulin superfamily" Mol Microbiol, 2003; 49:929-945.

[53] Artiushin S, Timoney JF, Nally J, Verma A, "Host inducible immunogenic sphingomyelinase-1ike protein, LK73.5, of Leptospira interrogans" Infect Immun, 2004; 72: 742-749.

[54] Koizumi N, Watanabe H, "Leptospiral immunoglobulin like proteins elicits protective immunity" Vaccine, 2004; 22:15451552
[55] Cullen PA, Haake DA, Adler B, "Outer membrane proteins of pathogenic spirochetes” FEMS Microbiol Rev, 2004; 28:291-318.

[56] Hsieh WJ, Chang YF, Chen CS, Pan MJ, “Omp52 is a growth phase regulated outer membrane protein of Leptospira santarosai serovar Shermani" FEMS Microbiol Lett, 2005; 243: 339-345.

[57] Nally JE, Whitelegge JP, Aguilera R, Pereira MM, Blanco DR, Lovett MA, "Purification and proteomic analysis of outer membrane vesicles from clinical isolate of Leptospira interrogans serovar Copenhageni" Proteomics, 2005; 5:144152.

[58] Elliott SH, "Discussion and clinical diagnosis of Leptospirosis" J Am Med Tech 1980: 42:37-44

[59] Faine S, “Guidelines for the control of leptospirosis' W. H. O. Offset publication no. 67. World Health Organization, Geneva. 1982.

[60] Weyant RS, Bragg SL, Kaufmann AF, Leptospira and Leptonema, p. 739-745. In Murray, P.R., E.J. Baron, M.A. Pfaller, F.C. Tenover and R.H. Yolken (Ed.). Manual of clinical microbiology, 7th ed. ASM Press, Washington, D.C. 1999.

[61] Ellinghausen HC, McCullough WG, "Nutrition of Leptospira pomona and growth of 13 other serotypes: fractionation of oleic albumin complex (OAC) and a medium of bovine albumin and polysorbate 80" Am J Vet Research, 1965; 26:45-51.

[62] Johnson R, Harris VG, "Differentiation of pathogenic of leptospires" J Bacteriol, 1967; 94:27-31.

[63] Rule PL, Alexander AD, "Gellan gum as a substitute for agar in leptospiral media' J Clin Microbiol, 1986; 23:500-504.

[64] Isenberg HD, Clinical microbiology procedures handbook. American Society for Microbiology, Washington, D.C. (Ed.). 1992.

[65] Koneman EW, Allen SD, Dowell VR, Janda WM, Sommers HM, Winn WC, Color atlas and textbook of diagnostic microbiology, 3rd ed. J.B. Lippincott Company, Philadelphia, PA. 1988

[66] Summaiya M, Tanvi HP, "Polymerase Chain Reaction: An Important Tool for Early Diagnosis of Leptospirosis Cases" J Clin Diagn Res, 2016; 10(12): DC08-DC11.

[67] Torten M, Shenberg E, Gerichter CB, Neuman P, Klingberg MA "A new leptospiral vaccine for use in man. II. Clinical and serologic evaluation of a field trial with volunteers" J Infect Dis, 1973; 128:647- 651 .

[68] Nomura S, Kishie B, Yoshikawa H, Noro M, Sakurai N, Akatsuka $\mathrm{Y}$, "Case reports on Weil's disease in Kumano district, Mie prefecture and vaccination (Japanese in original)" Media-circle, $1971 ; 40: 16-25$.

[69] EUROPEAN PHARMACOPOEIA (2002a). Monograph 01/2002:0447: Leptospira vaccine for veterinary use. EuropeanDirectorate for the Quality of Medicines and HealthCare (EDQM), Council of Europe, Strasbourg, France, p. 2270 .

[70] Kitaoka M, Inoue S, "Standard procedures of Weil's disease vaccine and Weil's disease and akiyami combined vaccine (Japanese in original)" Jpn Med J, 1952; 1478:2845- 2847.

[71] Lindblad EB, Freund's Adjuvants. In: O’Hagan D.T. (eds) Vaccine Adjuvants. Methods in Molecular Medicine ${ }^{\mathrm{TM}}$, vol 42. Springer, Totowa, NJ. (2000).

[72] Christine B, Adriana G, George CK, "Drawing Blood from Rats through the Saphenous Vein and by Cardiac Puncture" J Vis Exp, 2007; (7):266.

[73] Gorg AW, Postel S, Gunther, Whitaker, "Improved horizontal two-dimensional electrophoresis with hybrid isoelectric focusing in immobilized pH gradients in the first dimension and laying-on transfer to the second dimension" Electrophoresis, 1985; 6:599-60.

[74] Brandao AP, Camargo ED, da Silva ED, Silva MV, Abrao RV, "Macroscopic Agglutination Test for Rapid Diagnosis of Human Leptospirosis" J Clin Microbiol, 1998; 36(11):3138-3142. 
[75] Gomes-Solecki M, Santecchia I, Werts C, “Animal Models of Leptospirosis: Of Mice and Hamsters" Front Immunol, 2017; 8:58.

[76] White FH, Simpson CF, "The effect of formalin and other inactivators on the ultrastructure of leptospires" J Infect Dis, 1965; 115: 123-130.

[77] Suizer CR, Jones WL, Leptospirosis: methods in laboratory diagnosis. U.S. Department of Health, Education, and Welfare publication no. (CDC) 76-8275, p. 12-15. Center for Disease Control, Atlanta. 1980.

[78] Chen TZ, "Development and the present status of leptospiral vaccine and technology of vaccine production in china" Jap J Bacteriol, 1985; 40:755-762.
[79] Philip NA, Tennent RB, "Leptospirosis: a report on one practice on the use of a leptospiral vaccine for a period of 3 years" $\mathrm{N} \mathrm{Z}$ med J, 1966; 65:13-19.

[80] In: Faine S, Adler B, Bolin C, Perolat P. Leptospira and Leptospirosis, $2^{\text {nd }}$ edn. MediSci: Melbourne; 1999.

[81] Naiman BM, Alt D, Bolin CA, Zuerner R, Baldwin CL, "Protective killed Leptospira borgpetersenii vaccine induces potent Th1 immunity comprising responses by CD4 and gammadelta $\mathrm{T}$ lymphocytes" Infect Immun, 2001; 69(12):7550-7558.

[82] Samina I, Brenner J, Moalem U, Berenstein M, Cohen A, Peleg B, "Enhanced antibody response in cattle against Leptospira hardjo by intradermal vaccination" Vaccine, 1997; 15(12-13):1434-1436. 